\title{
An Archaeological Survey of Portions of the Chiltipin-san Fernado Creeks Watershed, Jim Wells County, Texas
}

Thomas R. Hester

Center for Archaeological Research

Feris A. Bass, Jr.

Follow this and additional works at: https://scholarworks.sfasu.edu/ita

Part of the American Material Culture Commons, Archaeological Anthropology Commons, Environmental Studies Commons, Other American Studies Commons, Other Arts and Humanities Commons, Other History of Art, Architecture, and Archaeology Commons, and the United States History Commons

Tell us how this article helped you.

This Article is brought to you for free and open access by the Center for Regional Heritage Research at SFA ScholarWorks. It has been accepted for inclusion in Index of Texas Archaeology: Open Access Gray Literature from the Lone Star State by an authorized editor of SFA ScholarWorks. For more information, please contact cdsscholarworks@sfasu.edu. 


\section{An Archaeological Survey of Portions of the Chiltipin-san Fernado Creeks Watershed, Jim Wells County, Texas}

\section{Creative Commons License}

\section{(c) (1) (8)}

This work is licensed under a Creative Commons Attribution-NonCommercial 4.0 International License 


\section{AN ARCHAEOLOGICAL SURVEY OF PORTIONS OF THE CHILTIPIN-SAN FERNANDO CREEKS WATERSHED, JIM WELLS COUNTY, TEXAS}

THOMAS R. HESTER AND FERIS A. BASS. JR.

THE CENTER FOR ARCHAEOLOGICAL RESEARCH

THE UNIVERSITY OF TEXAS AT SAN ANTONIO ARCHAEOLOGICAL SURVEY REPORT, NO. 4

NOVEMBER 25, 1974 

AN ARCHAEOLOGICAL SURVEY OF PORTIONS OF THE CHILTIPIN-SAN FERNANDO CREEKS WATERSHED JTM WELLS COUNTY, TEXAS

Thomas R. Hester and Feris A. Bass, Jr.

The Center for Archaeological Research The University of Texas at San Antonio Archaeological Survey Report No. 4

November 25, 1974 

TABLE OF CONTENTS

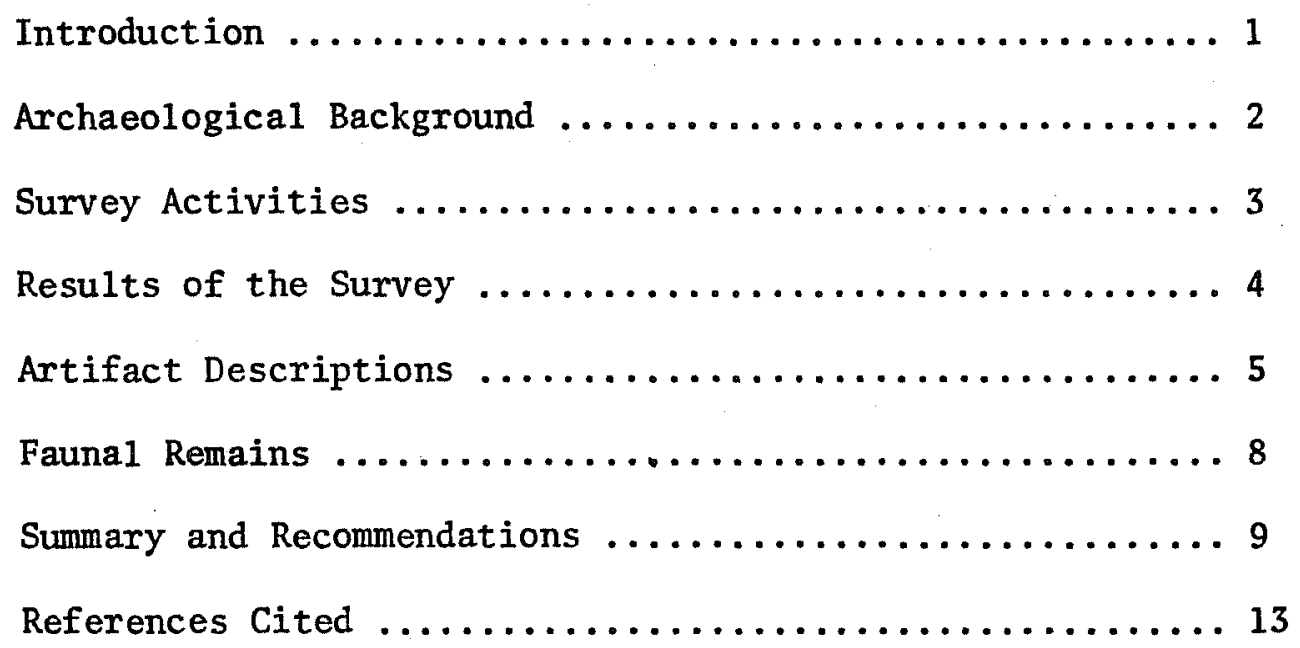

\section{LIST OF PIGURES}

Figure 1. Location of Archaeological Sites in the Area of Floodwater Retarding Structure No. 5. ...... 11

Figure 2. Artifacts from $41 \mathrm{JW} 7$ and 41 JW $8 . \ldots \ldots \ldots 12$ 



\section{INTRODUCTION}

In accordance with an agreement (Purchase Order No, 427-TX-SCS-75) between the U.S. Department of Agriculture Soil Conservation Service and the Center for Archaeological Research at The University of Texas at San Antonio, an archaeological survey was carried out in a portion of the Chiltipin-San Fernando Creeks Watershed in Jim Wells County, Texas (see Fig. 1). The specific area examined during the survey was the proposed site for Floodwater Retarding Structure No. 5 (Revised), encompassing 320 hectares (790 acres) and extending for approximately $3 \mathrm{~km}$ along the course of Chiltipin Creek (Fig. 1).

The purpose of the survey was to ascertain the existence of any historic or archaeological data which should be preserved in the public interest. Further requirements under the agreement with the Soil Conservation Service were:

1. Determine if archaeological resources exist within the area slated for modification.

2. If resources were found, to identify and appraise the significance of resources.

3. Evaluate the impact of project installation on each resource.

4. Provide the result in recommendations for mitigation of adverse impacts anticipated.

5. Provide estimate of costs required for mitigation (salvage, protection, etc.).

The survey area is along the course of Chiltipin Creek in northern Jim Wells County, on the Rio Grande Plain of southern Texas. It is an area of level to rolling terrain, with vegetation consisting primarily of mesquite and associated thorny brush, prickly pear, and grasses, with vegetative cover often very dense along the Chiltipin Creek channel. Other types of vegetation found along the channel include live oak, huisache, and hackberry. However, the present vegetational patterns apparently reflect conditions which have existed for only the past 100-150 years. For example, accounts of travelers passing through northern Jim Wells County in the early part of the 19 th century report a terrain dominated by a grassland prairie, a situation found over much of southern Texas between the Nueces River and the Rio Grande in the early historic period (cf. Price and Gunter 1943; Bogusch 1952; Ing1is 1964; Hester 1971). Benjamin Lundy crossed northern Jim Wells County in 1833 and noted that while the stream courses were well timbered, there was "scarce a bush" on the surrounding uplands; he further commented that the countryside was "abounding 

in excellent grass" (Inglis 1964: 35). By the time Havard crossed the same region in 1885, scrubby chaparral (mesquite and thorny shrubs) covered much of the area (Ibid.: 36).

The fauna of Jim Wells County is characteristic of the Tamaulipan Biotic Province (Blair 1950, 1952). Additional discussions of the vegetation and animal life of this region can be found in Hester (1972: 46-48).

\section{ARCHAEOLOGICAL BACKGROUND}

Jim Wells County, as well as most of southern Texas, was occupied at the time of historic contact by small groups of semi-nomadic hunters and gatherers known collectively as "Coahuiltecans". These native inhabitants were probably the descendants of peoples who had lived in the region for over 10,000 years. Descriptions of Coahuiltecan culture are provided elsewhere (Ruecking 1955; Newcomb 1961).

The prehistory of southern Texas has been summarized by Hester (1971a; 1974). Three major periods can be recognized, although they remain ill-defined at the present time: Paleo-Indian (roughly 9,200 6,000 B.C.; Clovis, Folsom, Plainview,Golondrina, and other diagnostic projectile points are occasionally found); Archaic (approximately 6,000 B.C. to A.D. 1200; numerous sites occur and are characterized by large numbers of stone tools, including triangular and stemmed dart points); Late Prehistoric (beginning after A.D. 1200 and lasting into protohistoric times, as late as A.D. 1700 in some areas; again, there are quite a number of sites, with arrow points, chipped stone tools, and bone-tempered pottery).

Archaeologically, Jim Wells County is poorly known. At the time our investigations were initiated, only six archaeological sites had been reported (these are in the files of the Texas Archeological Research Laboratory, Austin), and none of these from our area of study. Site 41JW2 has been briefly pub1ished by Shafer and Hester (1971: 8). It is located in the southern part of the county; the artifact assemblage consisted of Archaic and Late Prehistoric materials, including pottery. Also in the southern part of the county are three sites (41JW3-5) reported by Patterson (1974). He considers them to be of "late Archaic" age, although few diagnostic artifacts were collected.

Of particular relevance to archaeological studies along the ChiltipinSan Fernando Creeks Watershed are three published reports (Hester 1969, $197 \mathrm{lb}, 1973$ ) dealing with sites in adjacent Kleberg County. On the San Fernando Creek drainage in northwestern Kleberg County, Hester (1973) has reported site $41 \mathrm{KL} 54$, at which two burials and a small group of stone tools were found. Additionally, Hester $(1969,197 \mathrm{lb})$ has published 

a survey of archaeological sites in $\mathrm{Kleberg}$ County, including sites on the lower reaches of the San Fernando Creek drainage.

In adjacent Duval County to the west of the study area, a descriptive study of archaeological materials from three sites has been published (Hester 1972). Archaic and Late Prehistoric remains are present, including dart and arrow points, a wide variety of other chipped stone implements, and fragments of bone-tempered pottery.

\section{SURVEY ACTIVITIES}

Field inspection of the project area was carried out in November, 1974, by Feris A. Bass, Jr. (Research Associate of the Center) and Jules Jaquier, under the general supervision of Dr. Thomas R. Hester. Prior to the actual field work, the site records of the Texas Archeological Research Laboratory (The University of Texas at Austin) were examined to determine whether or not archaeological or historical resources had been previously reported in the survey area. It was ascertained that no such resources had been documented. The team's field work was greatly facilitated by the excellent cooperation of John Roberts, District Conservationist, Alice, Texas.

The purpose of Floodwater Retarding Structure No. 5 (revised) is to impound water behind an earthen dam during periods of heavy rainfall. This will minimize downstream flooding. The proposed dam site is to be located on the properties of Antonio Perez and R.D. and J.L. Hunter and will form the southern end of the proposed reservoir.

The survey was conducted on foot and consisted of a detailed inspection of the terrain throughout the entire detention pool area except where dense vegetation precluded surface examination. It was possible, however, to thoroughly inspect the locality in which the dam is to be built, but there were portions of the proposed detention pool on the Antonio Perez property which were impossible to examine because of the jungle-like growth along the creek channel. However, since clearings had been cut through this growth at several intervals it was possible to examine enough of the area to indicate to us that there was little likelihood of any significant archaeological resources occurring in that area. The Hunter property had been recently plowed both in the area of the detention pool and the proposed spillway.

The Fidencio Perez property had been developed into a cultivated pasture with heavy grass cover except along the immediate banks of Chiltipin Creek. No sites were observed in the pasture and none along the creek bank where the heavy vegetation could be penetrated. 

Because of landowner opposition to the proposed Soil Conservation Service project, the survey team was denied access to property bordering approximately $365 \mathrm{~m}$ (roughly $1200 \mathrm{ft}$ ) of both sides of Chiltipin Creek in the detention pool. This area has been developed into a cultivated pasture.

The balance of the detention pool area was entered at a point where a county road crosses the Chiltipin Creek on the Diana and Minerva Perez property. This property was also covered with a dense vegetative growth which impeded our inspection, except in areas where clearings had been cut along the United Gas Company pipeline. One small archeological site (41JW7) was identified on the Perez property on the east bank of the Chiltipin Creek adjacent to the Amargosa Cemetery.

The Clemente Hinojosa property was entered from the north and was found to be in cultivation (recently plowed) to within approximately 75 meters of the stream bed. An extremely interesting site (41JW8) was discovered along the eastern edge of this plowed field bordering Chiltipin Creek.

\section{RESULTS OF THE SURVEY}

Two archaeological sites were identified during the survey of Floodwater Retarding Structure No. 5 (Revised). These have been designated by the Texas Archeological Research Laboratory as sites $41 \mathrm{JW} 7$ and $41 \mathrm{JW} 8$. Notes and artifacts resulting from the documentation of these sites are on file at the Center for Archaeological Research, The University of Texas at San Antonio.

\section{JW 7 (Fig. 1)}

The site is located along the fringes of a eroded area on a stream terrace paralleling the east side of Chiltipin Creek. Cultural debris is found along a fence line approximately 35 meters due south of Amargosa cemetery and 75 meters east of the present Chiltipin Creek channel. A light scattering of burned rock (hearthstones), chert flakes, one projectile point fragment, and a small biface were collected from the eroded surface. The site appears to have seen only short-term use, perhaps as a temporary campsite. No further investigations are recommended.

\section{$41 \mathrm{JW} 8$ (Fig. 1)}

This is a large prehistoric occupation site on the west floodplain of Chiltipin Creek. It extends approximately 100 meters south from 
$$
\text { . }
$$ 
the intersection of the northern property line of the Clemente Hinojosa property and the creek. Part of the site had been disturbed by plowing which had exposed numerous burned rocks, large numbers of chert flakes, bifacial and unifacial tools, pottery sherds, mussel and snail shells, and a quantity of large, thick bone fragments (possibly bison). In addition to collecting all observable cultural materials from the site surface, a small shovel test was dug in the undisturbed area between the plowed field and the stream channel. Flakes, unifacial tools, and one pottery sherd were recovered from this minor test.

The site covers an area of about 5,000 square meters, and contains buried deposits at least $15 \mathrm{~cm}$ in depth. Although part of the site has been disturbed by agricultural activities, a sizable portion remains intact. This is apparently a major Late Prehistoric occupation site and we strongly recommend that extensive excavation be carried out prior to construction of the floodwater retarding structure. The site is well within the detention pool of the proposed reservoir and the north edge of the site borders the 50-year sediment pool.

\section{ARTIFACT DESCRIPTIONS}

The artifacts collected from sites $41 \mathrm{JW} 7$ and 41 JW 8 are described here. The following abbreviations are used in the descriptions: $L$, maximum length; $W$, maximum width; $T$, maximum thickness. Incomplete measurements are enclosed in parentheses. All measurements are in millimeters.

\section{JW 7}

Bifaces (Two specimens; Fig. 2, a, b)

One specimen is a medial fragment of a small, thick biface, probably a projectile point (Fig. 2,a). L, 28; W, 17; T, 10. The second biface (Fig. 2,b) is rectangular in outline and is beveled at one end. Although no diagnostic wear patterns are visible, the specimen may have possibly served as a scraper. It does, however, bear some resemblance to aboriginally-made gun flints of the early historic era. $\mathrm{L}, 30 ; \mathrm{W}, 22 ; \mathrm{T}, 8$. Both bifaces are made of white chert.

Cores (Three specimens; not illustrated)

Of the three specimens, only one is complete. It is an exhausted example, with one major simple prepared platform and one (or possibly two) facetted secondary platforms. It is made of white chert. L, 35; W, 23; T, 20. There are also two crudely flaked pieces of chert that probably represent core fragments. L, 40, 50; W, 29, 23; T, 20, 26 . 

Flakes (Five specimens; not illustrated)

Five chert flakes were collected from the site. All are highly fragmented. Using the flake categories of Hester and Hill (1973: 46) the specimens can be sorted as follows: interior flakes (three), secondary cortex flake (one), and primary cortex flake (one). One of the fragments may be the medial section of a blade.

\section{$41 \mathrm{JW} 8$}

Bifaces (Five specimens; Fig. 2, c-f)

Two of the bifaces are projectile points. One is a Perdiz arrow point (Fig. 2, c), and the other is a small, thick triangular specimen probably of the Matamoros type (Fig. 2, d). The Perdiz point has a broken stem and is made of tan-pink chert. L, (21); W, 16; T, 3. The Matamoros specimen is made of brown chert and bears evidence of repeated efforts (most of which were failures) to thin one of the lateral edges. $L, 31$; W, 20; T, 8 .

of the other three bifaces, one is a crude triangular specimen of white chert.(Fig. 2, f; L. 42; W, 27; T, 7) and the other two are thin biface fragments (Fig. 2,e).

Unifaces (Nine specimens; Fig. 2, g-1)

Five of the unifaces can be described as "end scrapers". They are thin, light flakes with a trimmed convex scraping edge, or bit, at one end (Fig. 2, g-k). Four are made on interior flakes and one, on a cortex flake. Two of the specimens are fragmentary, with the proximal ends missing.

All were examined under $80 \mathrm{X}$ magnification using a binocular stereomicroscope, in an effort to obtain functional information. The dimensions of the end-scraper series are given below, along with data derived from microscopic examination.

\begin{tabular}{|c|c|c|c|c|c|}
\hline Fig. & $\underline{L}$ & $\underline{W}$ & $\underline{T}$ & Edge Angle & Wear Evidence \\
\hline $2, g$ & 31 & 23 & 6 & $75^{\circ}-85^{\circ}$ & nibbling wear along bit \\
\hline $2, h$ & 28 & 20 & 6 & $58^{\circ}$ & nibbling wear along bit \\
\hline $2, i$ & 23 & 18 & 5 & $75^{\circ}$ & $\begin{array}{l}\text { entire bit edge very } \\
\text { heavily dulled and polished }\end{array}$ \\
\hline $2, j$ & (25) & 20 & 4 & $75^{\circ}$ & nibbling along bit \\
\hline $2, k$ & $(20)$ & 20 & 7 & $80^{\circ}$ & $\begin{array}{l}\text { nibbling, accompanied by } \\
\text { very light polish, along } \\
\text { bit }\end{array}$ \\
\hline
\end{tabular}



Three other unifacial specimens (not illustrated) can be termed "laterally trimmed flakes". All are fragmentary, but have one or both lateral edges steeply trimmed, possibly for use in cutting or scraping tasks. Two of the specimens are highly burned. Thickness of the specimens vary from 6-7 mm, and width, 14-22 mm.

One uniface is triangular in outline and is "gouge"-like (Fig. 2, 1). It is beveled at one end. This presumed working edge or bit was examined under $80 \mathrm{X}$ magnification. Near the middle of the edge (see Fig. 2, 1) is an area of heavy dulling and polishing. The polish extends onto the ventral face of the specimen. $L, 31 ; W, 33 ; T, 10$. Edge angle of the bit is $75^{\circ}$.

Flakes (103 specimens; not illustrated)

The flakes from 41 JW 8 reflect the utilization of small chert (flint) cobbles; there are also a few flakes of quartzitic material. Colors of chert represented in the sample include white (predominant), brown, pink, gray and tan. Most of the flakes are the byproducts of the stone tool manufacturing process. Only four specimens show some evidence of edge utilization, probably for casual cutting or scraping tasks. Using the categories and terminology of Hester and Hill (1973: 46), we have sorted the flakes into the following groups:

primary cortex (dorsal surface covered with nodular cortex); three specimens. A11 are sma11, less than $20 \mathrm{~mm}$ in maximum dimension. One has a cortex platform, while the striking platforms on the other two are single faceted.

secondary cortex (dorsal surface has some remnants of cortex, but also one or more flake scars); 25 specimens. These can be sorted into two categories on the basis of size: eight specimens, $42 \times 60 \times 12 \mathrm{~mm}$ to $43 \times 22 \times 13 \mathrm{~mm}$; 17 specimens, $14 \times 17 \times$ $3 \mathrm{~m}$ to $36 \times 26 \times 6 \mathrm{~m}$.

Seventeen specimens have single faceted striking platforms, six have cortex platforms, and the platforms on two others are multifacetted. Two specimens have been burned. Brown, white and gray cherts are predominant.

interior (no dorsal cortex); 24 specimens, mostly thin and small $(18 \times 17 \times 36 \mathrm{~mm}$ to $28 \times 38 \times 8 \mathrm{~mm})$. A1l are of chert. Fourteen have single faceted platforms, six have multifaceted platforms, and five have shattered striking platforms. One specimen is highly vitreous or glossy and may be from a heattreated nodule.

biface thinning flakes (resulting from the thinning of a bifacial edge); four specimens. Four have multifaceted platforms, and one, a single faceted platform. The platform edges of all have been dulled prior to flake detachment. Two of the biface thinning 

flakes are fragments; the other two have the following dimensions: $\mathrm{L}, 14,27 ; \mathrm{W}, 17,14$; $\mathrm{T}$ (at the platform), 3, 3 .

flake fragments (the platform and bulb of percussion are missing); 45 specimens. Of these, 23 have some remnants of dorsal cortex; five specimens have been burned. There are 42 flake fragments of chert and three of quartzite. Four flake fragments show some evidence of edge utilization.

blade (flake with a width twice that of its length, and with a longitudinal dorsal ridge); one specimen; the blade is of tan chert; it has a single faceted striking platform. L, 31; W, 11; $\mathrm{T}, 2.5$.

Other lithic debris aside from the above categories included three chunks (artifact waste of non-flake origin; cf. Hester and Hill, 1973: 49) and a "potlid" (a circular chert specimen resulting from intense thermal fracture of a chipped stone specimen).

\section{FAUNAL REMAINS}

Numbers of 1 and snails and mussel shell fragments, most of which presumably result from aboriginal food-collecting activities, were observed at site $41 \mathrm{JW} 8$. In addition, a sample of 21 pieces of large, thick (up to $12 \mathrm{~mm}$ ) mamma1 bone were picked up from the site surface and from the minor test cut. Some of these highly comminuted specimens appear to represent deer, but most are of larger mammals, probably bison. Some of the bone fragments are charred. 

In early November, 1974, personnel of the Center for Archaeological Research, The University of Texas at San Antonio, carried out an archaeological survey under an agreement with the Soil Conservation Service. The survey was of the area encompassed by the proposed Floodwater Retarding Structure No. 5 (Revised), in the Chiltipin-San Fernando Creeks Watershed, Jim Wells County, Texas. The survey team performed an onthe-ground inspection of the area, searching for any evidence of archaeolgoical or historical remains.

As a result of the field work, two archaeological sites were documented. One of these, $41 \mathrm{JW} 7$, is located on the east side of Chiltipin Creek. Scattered lithic materials had been exposed by erosion. The site was apparently used as a short-term camping spot and no significant buried deposits were found to exist. We have recommended that no further work be carried out at the site.

The second site, $41 \mathrm{JW} 8$, is a large occupation area located on the west floodplain of Chiltipin Creek. Surface collections and a minor test cut produced an assemblage of artifacts which can be linked primarily to the Late Prehistoric period. Of particular significance is the occurrence of aboriginal pottery and the presence of considerable amounts of animal bone, much of which appears to be bison. If the presence of bison at this site can be demonstrated, it would indicate that the range of these animals extended considerably farther to the south than commonly supposed (cf. Inglis 1964). The site area is quite extensive, and although a part of it has been disturbed by plowing, a substantial portion does remain intact. The nature of this site warrants its nomination to the National Register of Historic Places, and steps are presently being taken to accomplish this.

41 JW 8 will not be directly affected by the construction of the dam and spillway (see Fig. 1). However, the site is well within the confines of the detention pool (and adjacent to the sediment pool) and its proximity to the channel of Chiltipin Creek suggests that the site will be inundated whenever water is impounded behind the floodwater retarding structure. It is, therefore, our strong recommendation that an organized program of archaeological investigation be carried out at the site prior to completion of the project. The primary objective of these investigations should be extensive excavation, aimed at sampling at least $15 \%-20 \%$ of the remaining intact deposits at this significant site.

Sites like 41 JW 8 are quite rare in southern Texas and, when properly investigated, can provide the archaeologist with tremendous resources for studying the various aspects of Late Prehistoric lifeway in the region. In an earlier section, we briefly mentioned the kinds of archaeological sites that have previously been recorded in areas adjacent to Jim Wells 

County. The Late Prehistoric assemblage at $41 \mathrm{JW} 8$ has affinities with sites reported by Hester (1972) in Duval County, and certain late sites in the Kleberg County area (Hester 1969).

This Jim Wells County site is situated in an interesting geographic position, perhaps in what might be described as the "boundary" area between archaeological manifestations linked to peoples of the south Texas interior to the west and those found to the east, along the bayshores and the coast (the "savanna" and "maritime" adaptations hypothesized by Hester 1971a). The analysis of a comprehensive sample from site $41 \mathrm{JW} 8$ would be an important contribution in the continuing efforts to define and assess the variety of Late Prehistoric adaptations in the southern Texas area.

In accordance with the terms of our agreement with the Soil Conservation Service, we have prepared a budgetary estimate detailing the costs that might be anticipated in the course of mitigation activities. The proper investigation of site $41 \mathrm{JW} 8$ would require the services of a supervising archaeologist, a field archaeologist, two technical staff assistants, three laborers, necessary expendable supplies, transportation costs, the laboratory analysis of excavated materials (this includes a laboratory assistant), and the costs for preparing and publishing a scientific report. It is our estimate that a total expenditure of approximately $\$ 6,275$ will be required. 

This page has been

redacted because it

contains restricted

information. 



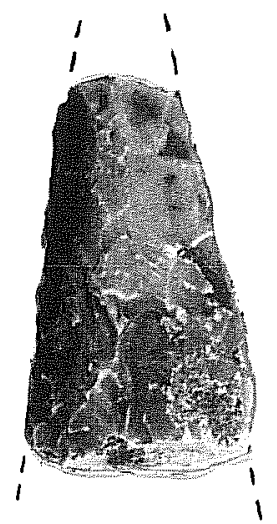

a

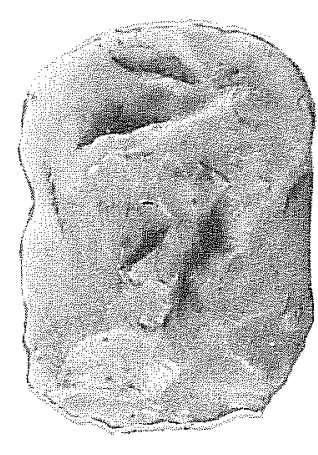

b

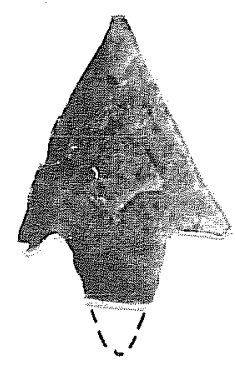

C

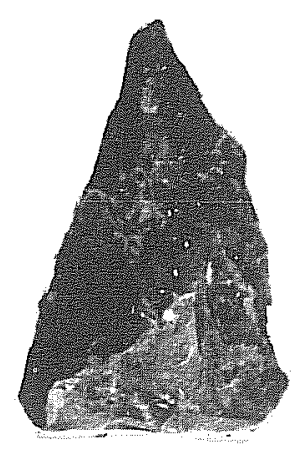

d

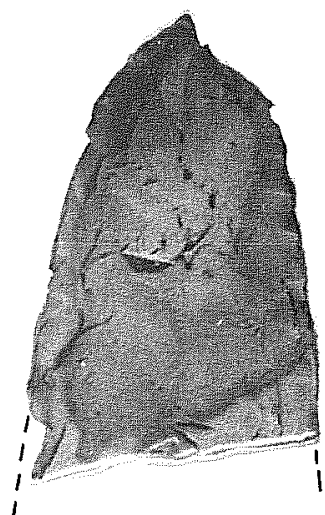

e

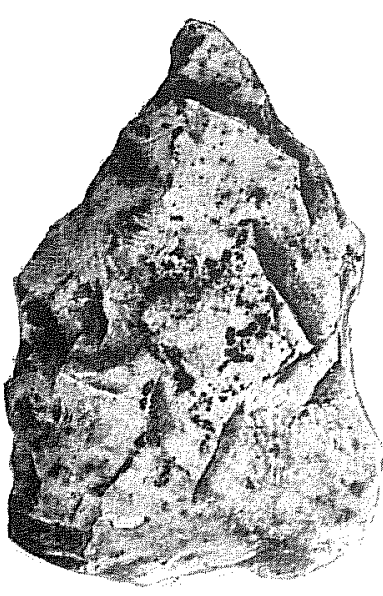

$f$

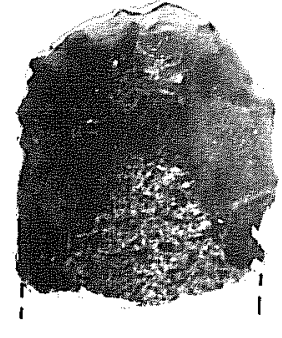

$\mathbf{k}$

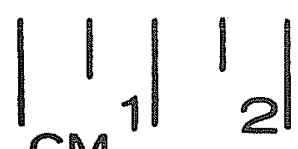

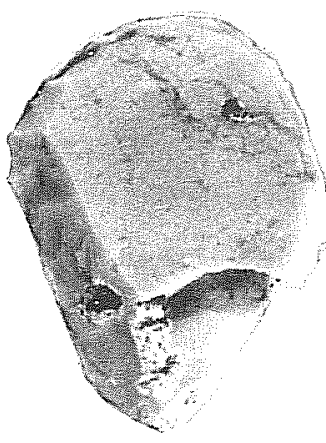

g
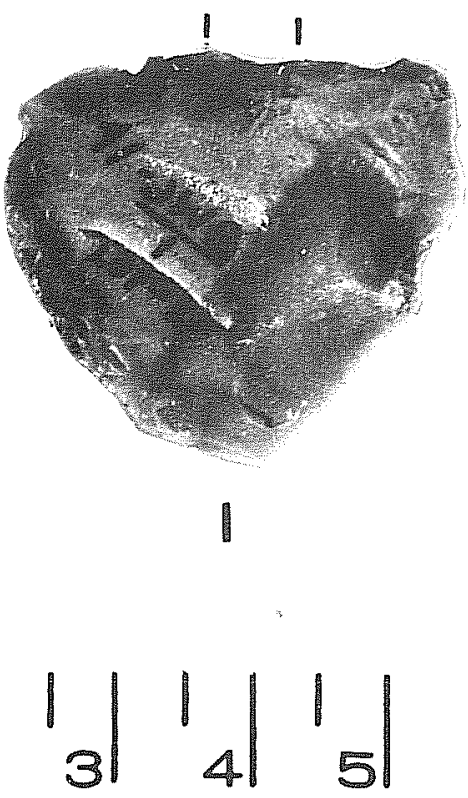
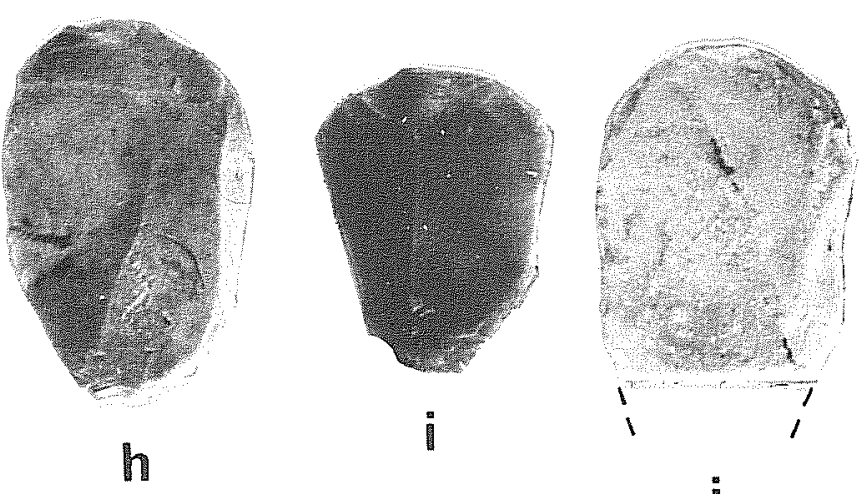

j

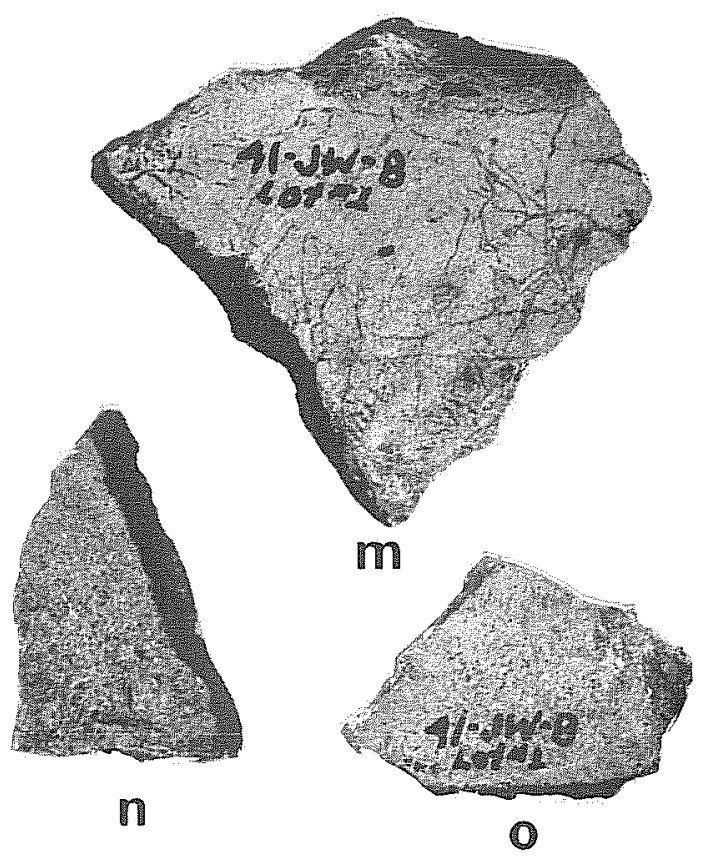

Figure 2. Artifacts from $41 \mathrm{JW} 7$ and $41 \mathrm{JW} 8$. a,b bifaces from $41 \mathrm{JW} 7$; c, Perdiz point, $41 \mathrm{JW} \mathrm{8;} \mathrm{d,} \mathrm{Matamoros} \mathrm{point,} 41 \mathrm{JW} 8$; e, f bifaces from $41 \mathrm{JW} 8 ; \mathrm{g}-1$, unifaces from $41 \mathrm{JW} 8$ (extent of polishing on 1 is indicated); m-o pottery sherds from $41 \mathrm{JW} 8$. 

Blair, W. F.

1950 The Biotic Provinces of Texas. Texas Journal of Science 2(1): $93-115$.

1952 Mammals of the Tamaulipan Biotic Province in Texas. Texas Journal of Science 4(2): 230-250.

Bogusch, E. R.

1952 Brush Invasion in the Rio Grande Plain of Texas. Texas Journal of Scierice 4(1): 85-91.

Hester, T. R.

1969 Archeological Investigations in Kleberg and Kenedy Counties, Texas, August, 1967. State Building Commission, Archeological Program, Report 15.

1971a Hunters and Gatherers of the Rio Grande Plain and the Lower Coast of Texas. Paper presented at the 74 th annual meeting of the Texas Academy of Science, Nacogdoches.

1971b Loyola Beach: An Example of Aboriginal Adaptation to the Maritime Environment of the Lower Texas Coast. Florida Anthropologist $24(3): 91-106$.

1972 The Surface Archeology of Three Sites in Duval County, Southern Texas. Bulletin of the Lower Plains Archeological Society 2: 45-71.

1973 Notes on an Archaeological Site in Kleberg County, Texas. Newsletter, Houston Archeological Society 41: 2-6.

1974 A Bibliographic Guide to the Archaeology of Southern Texas. Journal of South Texas 1: 18-36.

Hester, T. R. and T. C. Hill, Jr.

1973 Prehistoric Occupation at the Holdsworth and Stewart Sites on the Rio Grande Plain of Texas. Bulletin of the Texas Archeological Society 43: 33-65.

Inglis, J. M.

1964 A History of Vegetation on the Rio Grande Plain. Texas Parks and Wildlife Department Bulletin 45. 

Newcomb, W. W., Jr.

1961 The Indians of Texas, University of Texas Press, Austin. Patterson, L. M.

1974 Three Sites in Jim Wells County. La Tierra 1(2): 12-14.

Price, W. A. and G. Gunter

1943 Certain Recent Geological and Biological Changes in South Texas, with Consideration of Probable Causes. Proceedings and Transactions of the Texas Academy of Science, for 1942: 3-21.

Ruecking, F., Jr.

1955 The Coahuiltecan Indians of Southern Texas and Northeastern Mexico. M.A. thesis, University of Texas, Austin.

Shafer, H. J. and T. R. Hester

1971 A Study of the Function and Technology of Certain Bifacial Tools from Southern Texas. Texas Historical Survey Committee, Archeological Report 20. 
